\title{
Afatinib, Erlotinib and Gefitinib in the First-Line Therapy of EGFR Mutation-Positive Lung Adenocarcinoma: A Review
}

\author{
Jens Köhler $^{\mathrm{a}}$ Martin Schuler ${ }^{\mathrm{a}, \mathrm{b}}$ \\ aDepartment of Medical Oncology, West German Cancer Center, University Hospital Essen, \\ ${ }^{\mathrm{b}}$ Ruhrlandklinik, Division of Thoracic Oncology, University Duisburg-Essen, Essen, Germany
}

\section{Keywords}

EGFR mutation - Adenocarcinoma - First-line therapy . EGFR TKI · Erlotinib · Gefitinib · Afatinib

\section{Summary}

Non-small cell lung cancer (NSCLC) consists of several histomorphologically defined phenotypes that display an enormous genetic variability. In recent years, epidermal growth factor receptor (EGFR) mutation-positive lung adenocarcinoma has emerged as a unique subset of NSCLC in terms of etiopathogenesis and tumor biology. Since the introduction of the reversible EGFR tyrosine kinase inhibitors (TKIs) erlotinib and gefitinib, patients with metastatic EGFR mutation-positive lung cancer can be offered a therapeutic alternative that has proven its superiority over standard platinum-based chemotherapy. However, primary or acquired resistance limits the therapeutic success of these targeted agents. Irreversible inhibitors targeting all ErbB family receptor tyrosine kinases, such as afatinib and dacomitinib, have been developed to confer sustained disease control in ErbB-dependent cancers. The large LUX-Lung 3 phase III trial recently reported afatinib to be clearly superior over the most effective platinum doublet in patients with EGFR mutation-positive lung cancer. To fully exploit the clinical activity of afatinib, proactive management of its gastrointestinal and dermatologic toxicities is advised.

\section{Introduction}

Lung cancer is the leading cause of cancer-related mortality and contributes to more than 1 million deaths every year
Schlüsselwörter

EGFR-Mutation - Adenokarzinom - Erstlinienbehandlung · EGFR TKI · Erlotinib · Gefitinib · Afatinib

\section{Zusammenfassung}

Nichtkleinzellige Lungenkarzinome (NSCLC) umfassen verschiedene histomorphologische Subtypen, die eine große genetische Heterogenität aufweisen. Epidermaler Wachstumsfaktorrezeptor (EGFR)-mutierte Adenokarzinome der Lunge wurden in den letzten Jahren aufgrund ihrer einzigartigen Ätiopathogenese und Tumorbiologie als eigenständige Subentität innerhalb der NSCLC identifiziert. Seit Einführung reversibler EGFR-Tyrosinkinaseinhibitoren (TKIs) profitieren Patienten mit metastasierten EGFR-mutierten Lungenkarzinomen von den Medikamenten Erlotinib und Gefitinib, die der Standardtherapie aus Platin-basierten Kombinationschemotherapien überlegen sind. Der Erfolg dieser zielgerichteten Medikamente wird jedoch durch primäre und erworbene Resistenzen eingeschränkt. Um bei ErbB-abhängigen Tumoren auch weiterhin eine Tumorkontrolle zu erreichen, wurden Inhibitoren wie Afatinib und Dacomitinib entwickelt, die sämtliche Rezeptoren der ErbB-Familie irreversibel blockieren. Die kürzlich veröffentlichten LUXLung-3-Phase-III-Studiendaten zeigen eine deutliche Überlegenheit von Afatinib gegenüber der derzeit effektivsten Platin-basierten Kombinationschemotherapie bei Patienten mit EGFR-mutierten Adenokarzinomen der Lunge. Um die volle klinische Aktivität von Afatinib nutzen zu können, ist eine aktive Behandlung der gastrointestinalen und dermatologischen Nebenwirkungen erforderlich.

worldwide. Smoking is the main risk factor, but global statistics estimate that - considering vast regional variations about $15 \%$ of lung cancer deaths in men and up to $50 \%$ in women will occur in lifelong never-smokers $[1,2]$. This

\section{KARGER \\ Fax +497614520714 \\ Information@Karger.com}

www.karger.com (c) 2013 S. Karger GmbH, Freiburg

0378-584X/13/0369-0510\$38.00/0

Accessible online at:

www.karger.com/onk 
makes non-smoking-related lung cancer one of the 10 most common deadly cancers if considered as an independent entity. Furthermore, due to smoking cessation and prevention initiatives, never-smokers and former smokers will constitute a larger part of the overall lung cancer population in the future. In metastatic non-small cell lung cancer (NSCLC), different platinum-based chemotherapy regimens offer a moderate clinical benefit, with response rates of $20-35 \%$ and a median survival time of 10-12 months. Unfortunately, there have been only small improvements in long-term survival over the past decades [3]. This is, at least in part, due to the enormous biologic and genetic heterogeneity of the disease, which has traditionally been therapeutically addressed with a 'one-size-fitsall' approach. Against this simplistic view, there has been much interest in personalizing treatment concepts for lung cancer patients in recent years. This was stimulated by a tremendous gain in knowledge of genetic alterations in lung cancer cells and the successful examples of imatinib as a genotype-directed drug for $b c r$-abl-positive leukemias and $c$-kit mutation-positive gastrointestinal stroma tumors (GIST). This established a new paradigm of oncogene-targeted therapies in oncology $[4,5]$. Oncogenes code for proteins that are important for cell fate determinations and proliferation. They become activated during the multi-stage process of tumor-initiating events and/or tumor progression [6]. Once activated, oncogenes may render the cancer cell highly dependent on continued oncogene signaling, a phenomenon that is termed 'oncogene dependency' or 'oncogene addiction'. Weinstein and others first postulated that critical oncogenes may therefore represent a deadly weakness of the tumor - metaphorically speaking, the cancer's 'Achilles heel' - and a promising cellular target for cancer therapy [7].

In NSCLC and other epithelial malignancies, the epidermal growth factor receptor (EGFR) - first isolated by Stanley Cohen in 1962 [8] - as a member of the Her/ErbB receptor family has been identified as such a critical oncogene. Whereas non-malignant cells engage stringent regulatory programs for receptor tyrosine kinase (RTK) functions, the EGFR activity in cancer cells can be dysregulated by oncogenic mechanisms including increased EGFR gene copy number, EGFR overexpression, and activating gene mutations. This results in autophosphorylation of the cytoplasmic receptor domain and subsequently activates downstream signaling cascades including the mitogen-activated protein kinase (MAPK), mammalian target of rapamycin (mTOR), and Janus kinasesignal transducers and activators of transcription (JAK-STAT) pathways, amongst others [9]. These activated pathways may ultimately counteract apoptosis and enhance cellular metabolism and cell proliferation. They also impinge on metastatic spread, angiogenesis, and resistance to antineoplastic agents or radiotherapy, thereby conferring an inferior prognosis in many solid tumors $[10,11]$. Thus, the deregulated EGFR is a promising cellular target for the treatment of solid tumors and for lung cancer in particular.
Although the first anti-EGFR drugs were developed in the 1980s, small-molecule EGFR tyrosine kinase inhibitors (TKIs) like erlotinib (Tarceva $^{\circledR}$, Roche Pharma AG, GrenzachWhylen, Germany) and gefitinib (Iressa ${ }^{\circledR}$, AstraZeneca, Wedel, Germany) became clinically available for NSCLC treatment only during the last decade. Recently, afatinib (Gilotrif $^{\circledR}$, Boehringer Ingelheim GmbH, Ingelheim, Germany), a first-in-class irreversible ErbB family blocker, has been added to this therapeutic armamentarium [12-14].

\section{EGFR Mutation-Positive Lung Adenocarcinoma - a Distinct Subset of Lung Cancer with Responsiveness to EGFR TKIs}

Lung tumors exhibit frequent genetic and epigenetic aberrations with an, on average, 10-fold higher overall mutation frequency in smokers than in never-smokers [15]. EGFR is highly expressed on the cell surface of a substantial percentage of smoking- and non-smoking-related NSCLC (>60\%) [16], but only few tumors harbor activating EGFR gene mutations [17]. The etiology of these mutations still remains unknown; however, at least in some cases, they seem to represent an early carcinogenic event. They are not merely found in the tumor itself, but also in normal respiratory epithelium of lung cancer patients, in atypical adenomatous hyperplasia, in lung cancer founder clones, and in rare cases even in the germ line [18-20]. Since their initial description in $2004[17,21]$, many of these activating mutations have been discovered; they are all found in the first 4 exons [18-21] of the RTK domain. In-frame deletions in exon 19 (conferring a loss of 9-24 base pairs) and point mutations in exon 21 (leading to a base substitution of arginine to leucine at residue 858 ) are clinically most relevant, representing about $85-90 \%$ of all EGFR mutations [22]. In unselected patients, clinicopathological features like adenocarcinoma histology ( $40 \%$ vs. $3 \%$ in other histologies), East Asian descent (30\% vs. $8 \%$ in non-Asians), female sex (42\% vs. $14 \%$ in male patients), and particularly never-smoking status (51\% vs. $10 \%$ in current or ever-smokers) are associated with an increased EGFR mutation frequency within the tumor [23]. Therefore, it has been postulated that they can serve as surrogates for the molecular marker. Furthermore, the mutation frequency is higher in the micropapillary-predominant and the lepidiccomponent adenocarcinoma subtypes [24]. Because of the strong association to the non-smoking status, EGFR mutationpositive lung adenocarcinoma and lung cancer in neversmokers as such are nowadays considered as distinct biological tumor subsets in the view of molecular pathogenesis [25]. Affected patients appear to have a better prognosis even when they are treated with cytotoxic chemotherapy [26-28]. In contrast to patients with EGFR wild-type tumors, they benefit from EGFR TKI treatment in terms of higher objective response rates (ORR), longer progression-free 
survival (PFS), and/or longer median overall survival (OS) times $[17,21,22,29]$. This is at least in part due to a higher TKI potency against mutant EGFR compared to wild-type EGFR in terms of ATP competition [30] and the absence of activating $K R A S$ mutations, which usually occur after a substantial cigarette abuse and lead to EGFR TKI resistance [31]. The socio-economic impact of lung adenocarcinoma will prospectively increase in the future, as there has been accumulating evidence on sustained rising incidence rates in Asian and non-Asian populations for several decades, presumably due to changes in smoking habits and exposure to environmental carcinogens [32].

\section{Erlotinib and Gefitinib in the First-Line Treatment of EGFR Mutation-Positive NSCLC}

Initial phase II trials of erlotinib and gefitinib in the firstline setting demonstrated at best modest efficacy in unselected patients, with rather disappointing response rates (4-23\%), PFS (1.6-3.5 months) and OS times (5-13 months) [33-39] (table 1). This was in accordance with results of the large second- and third-line trials BR.21 and ISEL, demonstrating a rather minor clinical benefit of EGFR TKI therapy compared to placebo in a likewise unselected patient population $[12,13]$. Subgroup analyses and the discovery of activating EGFR

Table 1. Selected studies reporting the activity of first-line erlotinib and gefitinib in NSCLC

\begin{tabular}{|c|c|c|c|c|c|c|}
\hline Study & Study phase & Population & Treatment (patients, n) & ORR, \% & $\begin{array}{l}\text { Median PFS/TTP, } \\
\text { months }\end{array}$ & $\begin{array}{l}\text { Median OS, } \\
\text { months }\end{array}$ \\
\hline \multicolumn{7}{|c|}{ Patients not selected for TKI sensitivity } \\
\hline Giaccone [33] & phase II & unselected & erlotinib (53) & 22.7 & 2.8 & 13 \\
\hline Reck [34] & phase II & unselected & gefitinib (58) & 5.0 & 1.7 & 7.2 \\
\hline Akerley [35] & phase II & unselected & erlotinib (40) & 15 & 2.0 & 11.7 \\
\hline Jackman [36] & phase II & elderly & erlotinib (80) & 10 & 3.5 & 10.9 \\
\hline \multirow[t]{2}{*}{ INVITE [38] } & phase II & elderly & gefitinib (97) & 3.1 & 2.7 & 5.9 \\
\hline & & & vinorelbine (99) & 5.1 & $\begin{array}{l}2.9 \\
\text { HR 1.19; } p=0.31\end{array}$ & 8.0 \\
\hline Hesketh [37] & phase II & poor PS & erlotinib (76) & 8.0 & 2.1 & 5.0 \\
\hline \multirow[t]{3}{*}{ Lilenbaum [39] } & phase II & poor PS & erlotinib (52) & 2.0 & 1.9 & 6.5 \\
\hline & & & Carbo/Pac (51) & 12.0 & 3.5 & 9.7 \\
\hline & & & & & HR $1.45 ; p=0.06$ & \\
\hline \multicolumn{7}{|c|}{ Patients clinically selected for TKI sensitivity } \\
\hline Niho [44] & phase II & Asian & gefitinib (40) & 30 & NA & 13.9 \\
\hline Yang [43] & phase II & Asian & gefitinib (106) & 50.9 & 5.5 & 22.4 \\
\hline Ebi [46] & phase II & Asian, elderly & gefitinib (49) & 25 & 4.0 & 10 \\
\hline West [101] & phase II & BAC & gefitinib (104) & 17 & 4.0 & 13 \\
\hline Cadranel [102] & phase II & $\mathrm{BAC}$ & gefitinib (88) & 12.9 & 2.9 & 13.2 \\
\hline Lee $[103]$ & phase II & $\begin{array}{l}\text { Asian, adenocarcinoma, } \\
\text { never-smokers }\end{array}$ & gefitinib (36) & 69 & 8.2 & 20.1 \\
\hline Jackman [104] & phase II & $\begin{array}{l}\text { female, adenocarcinoma, } \\
\text { never-smokers, } \\
\text { former-smokers }\end{array}$ & erlotinib (84) & 32 & 5.6 & 22.7 \\
\hline \multirow[t]{3}{*}{ IPASS [45] } & \multirow[t]{3}{*}{ phase III } & \multirow{3}{*}{$\begin{array}{l}\text { Asian, adenocarcinoma, } \\
\text { never-smokers, former } \\
\text { light-smokers }\end{array}$} & gefitinib (609) & 43.0 & 5.7 & 18.8 \\
\hline & & & Carbo + Pac (608) & 32.2 & 5.8 & 17.4 \\
\hline & & & & $\mathrm{p}<0.001$ & HR $0.74 ; p<0.001$ & $\mathrm{p}=0.109$ \\
\hline \multirow[t]{3}{*}{ First-SIGNAL [105] } & \multirow[t]{3}{*}{ phase III } & \multirow{3}{*}{$\begin{array}{l}\text { Asian, adenocarcinoma, } \\
\text { never-smokers }\end{array}$} & gefitinib (159) & 55 & 5.8 & 22.3 \\
\hline & & & Cis + Gem (150) & 46 & 6.4 & 22.9 \\
\hline & & & & $\mathrm{p}=0.101$ & HR $1.19 ; p=0.138$ & $\mathrm{p}=0.604$ \\
\hline \multicolumn{7}{|c|}{ Patients molecularly selected for TKI sensitivity } \\
\hline Asahina [106] & phase II & EGFR M+ & gefitinib (16) & 75 & 8.9 & NA \\
\hline Inoue [107] & phase II & EGFR M+ & gefitinib (16) & 75 & 9.7 & NA \\
\hline Sequist [108] & phase II & EGFR M+ & gefitinib (31) & 55 & 9.2 & 17.5 \\
\hline Rosell [109] & phase II & EGFR M+ & erlotinib (217) & 70.5 & 14 & 27 \\
\hline Inoue $[110]$ & Phase II & EGFR $\mathrm{M}+$, poor PS & gefitinib (30) & 66 & 6.5 & 17.8 \\
\hline \multirow[t]{3}{*}{ NEJSG002 [48] } & \multirow[t]{3}{*}{ phase III } & \multirow[t]{3}{*}{ EGFR M+ } & gefitinib (115) & 73.7 & 10.8 & 30.5 \\
\hline & & & Carbo + Pac (115) & 30.7 & 5.4 & 23.6 \\
\hline & & & & $\mathrm{p}<0.001$ & HR $0.30 ; p<0.001$ & $\mathrm{p}=0.31$ \\
\hline \multirow[t]{3}{*}{ WJTOG3405 [50] } & \multirow[t]{3}{*}{ phase III } & \multirow[t]{3}{*}{ EGFR M+ } & gefitinib (88) & 62.1 & 9.2 & 36 \\
\hline & & & Cis + Doc (89) & 32.2 & 6.3 & 39 \\
\hline & & & & $\mathrm{p}<0.0001$ & HR 0.48; $p<0.0001$ & HR 1.18 \\
\hline \multirow[t]{3}{*}{ OPTIMAL [47] } & \multirow[t]{3}{*}{ phase III } & \multirow[t]{3}{*}{ EGFR M+ } & erlotinib (82) & 83 & 13.1 & NA \\
\hline & & & Carbo + Gem (72) & 36 & 4.6 & NA \\
\hline & & & & $\mathrm{p}<0.0001$ & HR 0.16; $p<0.0001$ & $\mathrm{p}=\mathrm{NS}$ \\
\hline \multirow[t]{3}{*}{ EURTAC [49] } & \multirow[t]{3}{*}{ phase III } & \multirow[t]{3}{*}{ EGFR M+ } & erlotinib $(86)$ & 58 & 9.7 & 22.9 \\
\hline & & & Carbo/Cis + Doc/Gem (87) & 15 & 5.2 & 18.8 \\
\hline & & & & $\mathrm{p}<0.0001$ & HR $0.37 ; \mathrm{p}<0.0001$ & $\mathrm{p}=0.41$ \\
\hline
\end{tabular}

TTP $=$ Time to progression, PS = performance status, BAC = bronchoalveolar carcinoma, EGFR M+ = EGFR mutation-positive,

Carbo $=$ carboplatin, $\mathrm{Pac}=$ paclitaxel, $\mathrm{Cis}=$ cisplatin, $\mathrm{Gem}=$ gemcitabine, Doc $=$ docetaxel, NA $=$ not applicable, NS $=$ not significant. 
gene mutations as predictors for TKI effectiveness [17, 21, 33, $35,36]$ since then yielded a conceptual change in selecting patients for EGFR-targeted therapies. Some of the upcoming trials have used clinical criteria (such as smoking status, sex, histology, and ethnicity) and some have used the EGFR mutational status, whereas others have selected patients with potential intolerance to chemotherapy based on poor performance status and higher age. The latter concept, selecting patients who were expected to be intolerant of first-line chemotherapy, did not demonstrate superiority of EGFR TKI over standard of care [37, 39-42]. In contrast, several phase II trials, and in particular the phase III study IPASS, selected patients for clinical surrogate markers (i.e. female patients, Asians, never- or former light-smokers). All of these trials reported an increase in ORR (13-43\%) and PFS (4-5.9 months). Additional EGFR-mutational analyses revealed that the benefit was consistently highest in patients with tumors harboring the activating EGFR gene mutations [36, 43-46] (table 1). These findings eventually stimulated 4 randomized phase III trials comparing first-line erlotinib or gefitinib with cytotoxic chemotherapy in patients with proven EGFR-mutant NSCLC. In such molecularly selected populations, the OPTIMAL, WJTOG3405, and NEJSG002 trials in Asian patients and the EURTAC trial in Caucasian patients clearly demonstrated the superiority of erlotinib or gefitinib over platinum doublet chemotherapy - the standard of care - in terms of PFS (OPTIMAL: 13.1 vs. 4.6 months, hazard ratio (HR) 0.16; WJTOG3405: 9.2 vs. 6.3 months, HR 0.48; NEJSG002: 10.8 vs. 5.4 months, HR 0.30; EURTAC: 9.7 vs. 5.2 months, HR 0.37). Also the objective response rate was more than doubled in the EGFR TKI arms (OPTIMAL: 83\% vs. 36\%; WJTOG3405: $62 \%$ vs. $32 \%$; NEJSG002: $74 \%$ vs. $31 \%$; EURTAC: $58 \%$ vs. $15 \%$ ) [47-50]. Recently published meta-analyses consistently confirmed that EGFR mutations predict response to EGFR TKI with much higher sensitivity $(0.78 ; 95 \%$ confidence interval (CI) 0.74-0.82) than do EGFR gene copy numbers or EGFR expression levels [51]. First-line treatment with erlotinib or gefitinib in molecularly selected patients increases the chance of obtaining an ORR more than 2 -fold (70\% vs. $33 \%$ ) when compared to chemotherapy (relative risk (RR) 2.06; $2 \mathrm{p}<0.00001)$. At the same time, the hazard of progression is reduced by $65 \%($ HR $0.35 ; 2 p<0.00001)$ [52]. In EGFR mutation-positive patients treated with erlotinib or gefitinib, those with exon 19-deleted tumors appear to have a longer PFS (14.6 vs. 9.7 months) and OS (30.8 vs. 14.8 months) as compared to patients with EGFR L858R-mutant tumors [53, 54], although this was not consistently reproducible throughout all trials $[48,50,55]$. The European Medicines Agency (EMA) approved gefitinib in 2009 due to results from the IPASS and INTEREST trials, and erlotinib in 2011 due to EURTAC trial results for the first-line treatment of patients with EGFRmutant NSCLC, but both drugs have yet to be licensed for this indication by the U.S. Food and Drug Administration (FDA). This is in part due to the fact that none of these trials nor the meta-analysis (HR 0.96, 2p = 0.71) has actually demonstrated a significant improvement in OS for recipients of first-line EGFR TKI therapy [52]. There is evidence, however, that the response rates are higher when TKIs are given upfront to chemotherapy-naive patients compared to chemotherapytreated patients [56]. It is highly unlikely that such an overall survival advantage will ever be demonstrated, as nearly all patients with known $E G F R$ mutations who receive first-line chemotherapy cross over to TKI treatment. Furthermore, EGFR TKIs are also active in the second-line and maintenance treatment (SATURN, INFORM trial) - especially in EGFR-mutant tumors $[57,58]$. Anyhow, given that in many trials the HR for OS was slightly in favor of first-line EGFR TKI [52] and that the quality of life was maintained for much longer in TKI-treated patients [59], it is concluded that patients with EGFR-mutant tumors gain the greater benefit when TKIs are given early during the natural course of the disease [56]. Especially patients who are older or have a poor performance status will derive a greater benefit from first-line EGFR TKIs [46, 60]. These trials also clearly show that proper selection of patients is absolutely crucial for treatment with EGFR-targeted agents in both directions. First-line EGFR TKIs in patients with unknown or wild-type EGFR status were detrimental in terms of PFS and OS as compared to chemotherapy $[45,61,62]$. In line with this, early trials combining EGFR TKIs with first-line chemotherapy in unselected patients (INTACT-1 and -2 trials) did not lead to an increased treatment efficacy $[63,64]$, but recent trials in selected patients suggest that a combination may work (CALGB 30406 trial) [65].

\section{Afatinib - an Irreversible ErbB Family Blocker}

Tumors harboring drug-sensitive EGFR mutations that initially respond to first-generation EGFR TKIs eventually acquire resistance, which is observed after, on average, 9-13 months of treatment $[47-50,66]$. This is most likely due to selection of TKI-resistant subclones, which either pre-exist or newly emerge as a result of cancer-inherent genomic instability. Approximately $50 \%$ of these cases of acquired resistance to erlotinib or gefitinib harbor the EGFR T790M mutation, which appears to increase the ATP affinity to the level of the wild-type EGFR kinase and thereby closes the 'therapeutic window' for ATP-competitive EGFR TKIs [67]. The mutation may be also present in a minor population of EGFR TKInaive tumor cells and thus confer primary resistance [68]. Other mechanisms of acquired resistance include small-cell histologic transformation, tumor stroma-mediated effects, or up-regulation of parallel signaling pathways, e.g. via insulinlike growth factor-1 receptor (IGF1R), c-Met, or human epidermal growth factor receptor (HER)2 [69-71]. The latter can augment the mitogenic EGFR signal, and somatic HER2 mutations or amplifications and HER2 overexpression have been 
Table 2. Studies reporting the activity of first-line afatinib in NSCLC

\begin{tabular}{|c|c|c|c|c|c|c|}
\hline Study & Study phase & Population & $\begin{array}{l}\text { Treatment } \\
\text { (patients, } \mathrm{n})\end{array}$ & ORR, \% & $\begin{array}{l}\text { Median PFS/TTP, } \\
\text { months }\end{array}$ & $\begin{array}{l}\text { Median OS, } \\
\text { months }\end{array}$ \\
\hline LUX-Lung 2 [14] & phase II & EGFR M+ & $\begin{array}{l}\text { afatinib } 50 \mathrm{mg}(99) \\
\text { afatinib } 40 \mathrm{mg}(30)\end{array}$ & $\begin{array}{l}62 \\
60\end{array}$ & 12 (13.7 Del19/L858R) & 24 \\
\hline $\begin{array}{l}\text { LUX-Lung } 3 \text { [55] } \\
\quad \text { (worldwide) }\end{array}$ & phase III & EGFR M+ & $\begin{array}{l}\text { afatinib (230) } \\
\text { Cis/Pem (115) }\end{array}$ & $\begin{array}{l}56 \text { (61 Del19/L858R) } \\
23 \text { (22 Del19/L858R) }\end{array}$ & $\begin{array}{c}11.1 \text { (13.6 Del19/L858R) } \\
6.9 \text { (6.9 Del19/L858R) }\end{array}$ & NA \\
\hline LUX-Lung 6 (Asia) & phase III & EGFR M+ & $\begin{array}{l}\text { afatinib } 40 \mathrm{mg} \\
\text { Cis/Gem } \\
\text { ( } 330 \text { planned) }\end{array}$ & $\begin{array}{l}\mathrm{p}<0.0001 \\
\text { observation period; } \\
\text { results pending }\end{array}$ & $\begin{array}{l}\text { HR } 0.58 ; p=0.0004 \\
\text { still recruiting }\end{array}$ & still recruiting \\
\hline
\end{tabular}

detected in about $2 \%, 2-10 \%$, and $40 \%$ of lung adenocarcinomas, respectively $[72,73]$. Furthermore, a compensatory shift in the phosphorylation-dephosphorylation equilibrium of HER3, which itself lacks kinase activity but forms heterodimers with other ErbB family members, can induce resistance to first-generation EGFR TKIs [74]. This provides a strong rationale for a combined EGFR/HER2/HER3 blockade. Against this background, the orally available TKI afatinib has been developed, which covalently binds the RTK domains and equipotently inhibits EGFR, HER2 and HER4 and the transphosphorylation of HER3. The in vivo activity of afatinib against T790M-mutant NSCLC has not been shown so far; however, the inhibitor has proven in vitro activity against lung cancer cells with the EGFR T790M mutation, and also against cells with additional resistance mutations such as EGFR T854A and the variant III deletion (EGFRvIII) [75, 76]. The LUX-Lung 2 trial explored the 40 and $50 \mathrm{mg}$ once-daily dosage in TKI-naive patients and showed equal efficacy [14]. In the situation of acquired resistance, i.e. in TKI-pretreated patients, a higher dosage is needed, as indicated by in vitro data [76]. In this situation, the recommended starting dosage is $50 \mathrm{mg}$ once a day, as used in the LUX-Lung 1 and 4 trials $[77,78]$. The LUX-Lung 1 phase IIB/III trial investigated afatinib versus placebo in NSCLC patients who were progressing after prior treatment with at least 1 line of platinum-based chemotherapy and erlotinib or gefitinib. Patients were clinically enriched by enrolling only those who derived a minimum of 12 weeks of disease control under a first-generation EGFR TKI. However, afatinib did not meet the primary endpoint of extending OS compared to placebo (10.8 vs. 12 months, HR $1.08,95 \%$ CI $0.86-1.35)$, presumably due to subsequent therapies; PFS was (though in both groups rather mean in this clinical situation) in favor of afatinib (3.3 vs. 1.1 months, HR 0.38; $p<0.0001)$, with some improvement in cancer-related symptoms [77]. The LUX-Lung 2 trial, a phase II study, narrowed the study population to patients with advanced NSCLC (stage IIIB with pleural effusion and stage IV) harboring activating EGFR gene mutations who had 0 or 1 line of prior chemotherapy but were naive for EGFR TKIs. The overall response rates were similar with once-daily dosing of 40 or $50 \mathrm{mg}$ afatinib ( $60 \%$ for $40 \mathrm{mg}$ vs. $62 \%$ for $50 \mathrm{mg}$ ), but more side effects were observed in the group receiving $50 \mathrm{mg}$ [14]. Based on these findings, LUX-Lung 3, the so far largest registrational phase III trial in EGFR mutation-positive adenocarcinoma (345 patients randomized), randomized $40 \mathrm{mg}$ once daily of afatinib versus a highly effective and tolerable combination chemotherapy consisting of cisplatin and pemetrexed. The trial was conducted throughout Asia, Europe, North/South America, and Australia, with $72 \%$ of enrolled patients having Asian ethnicity and $28 \%$ being non-Asians. Treatment with afatinib led to a prolonged PFS (11.1 vs. 6.9 months, HR 0.58 , 95\% CI $0.43-0.78$ ) compared to cisplatin/pemetrexed and a significantly higher ORR ( $56 \%$ vs. $23 \%$; p < 0.0001$)$, as assessed by independent review $[79,80]$. The superiority of afatinib was consistent in all relevant subgroups. In those 308 patients with common EGFR mutations (i.e. exon 19 deletion or EGFR L858R) the median PFS even reached 13.6 months with afatinib versus 6.9 months with chemotherapy (HR 0.47, 95\% CI 0.34-0.65) (tables 1 and 2). As with erlotinib and gefitinib, patients with EGFR exon 19-deleted tumors appeared to have a greater benefit from afatinib (HR 0.28, 95\% CI 0.18 $0.44)$ than patients with EGFR L858R-mutant tumors (HR $0.73,95 \%$ CI $0.46-1.17)$. The afatinib group furthermore demonstrated a significant delay in time to deterioration of cancer-related symptoms such as cough (HR 0.6; $\mathrm{p}=0.007)$ and dyspnea (HR 0.68; $\mathrm{p}=0.015$ ) and increased quality of life [55]. OS data have yet to be reported. Currently recruiting trials compare afatinib in the first line against cisplatin/gemcitabine (LUX-Lung 6) in Asian patients, and head-to-head against gefitinib in the first-line treatment (LUX-Lung 7, phase IIB) of EGFR mutation-positive NSCLC, and with erlotinib in the second-line treatment (LUX-Lung 8, phase III) of NSCLC patients with squamous histology.

\section{Adverse Events Related to First-Line Treatment with EGFR TKIs and ErbB Family Blockers}

EGFR-targeting agents are generally associated with less serious toxicities than traditional anti-neoplastic agents. The latter confer the risk of organ toxicities, severe myelosuppression, and neutropenic sepsis, with treatment-related fatal 
Table 3. Reported incidences of common side effects of first-line EGFR TKIs in NSCLC (only phase III trials)

\begin{tabular}{lllr}
\hline Drug & Rash and acne (grade $\geq 3)$ & Diarrhea $($ grade $\geq 3)$ & Fatigue $($ grade $\geq 3)$ \\
\hline Afatinib 40/50 mg & $89(16)$ & $95(14)$ & $18(1)$ \\
Erlotinib 150 mg & $73-80(2-13)$ & $25-57(1-5)$ & $5-57(0-6)$ \\
Gefitinib 250/500 mg & $66-85(2-5)$ & $34-54(1-4)$ & $11-39(2-3)$ \\
\hline
\end{tabular}

events in up to $8 \%$ of patients, especially if the performance status is poor [81]. Fatal events during EGFR TKI treatment have been rarely reported; they were mainly associated with lung or liver toxicity $[14,48,82,83]$. Nevertheless, side effects can be severe and may substantially impair the quality of life. The most common adverse events leading to TKI dose reductions are cutaneous reactions (acneiform 'rash'), paronychia, and diarrhea, because of the abundance of EGFR in skin and mucosa. In a recent published meta-analysis, the appearance of skin rash has been confirmed as an independent predictive factor for survival (HR 0.30; $<<0.00001$ ) and tumor progression (HR 0.50; $\mathrm{p}<0.00001$ ) during erlotinib and gefitinib treatment [84]. In first-line NSCLC trials of erlotinib and gefitinib, most patients developed rash of grades 1 or 2 . Only a few patients experienced grade 3 rash (erlotinib: $67 \%, 2-13 \%$ grade $\geq 3$; gefitinib: $66 \%, 3 \%$ grade $\geq 3$ ) (table 3 ). Skin reactions normally appear after 1 week and reach maximum severity following 2-3 weeks of TKI treatment, after which they gradually and spontaneously disappear. Therefore, early clinical monitoring and intervention are mandatory to prevent serious complications. In this context, many reviews and treatment consensus papers have dealt with the question of how to cope with EGFR TKI-induced cutaneous reactions [85, 86]. Diarrhea also affects a substantial part of EGFR TKI-treated patients. It is thought to result from excess chloride secretion ('secretory diarrhea'), which can lead to dehydration, electrolyte imbalances, renal insufficiency, and malnutrition [86]. As diarrhea is a common side effect of conventional cancer treatment regimens, management in the oncology setting is much better established compared to the management of skinrelated events $[87,88]$. In first-line NSCLC trials, the diarrhea incidence was reported as high as $52 \%$ ( $5 \%$ grade $\geq 3)$ for erlotinib and $47 \%$ (4\% grade $\geq 3$ ) for gefitinib [47-50]. A much less frequent, yet potentially lethal (30-50\% lethality) side effect of EGFR TKIs is interstitial lung disease (ILD), which in general occurs during the first 3 months of treatment (median 24-42 days) in $<1 \%$ of all patients, with higher risk in Japanese populations (1.6-3.5\%) [82]. Pre-existing pulmonary fibrosis, prior thoracic irradiation, and smoking history have been identified as further risk factors for developing ILD and should be taken into account when considering a patient for first-line EGFR TKI treatment [89]. Other, mostly reversible side effects include fatigue, nausea/vomiting, and increased liver enzyme levels [45, 49, 50, 55]. Overall, for the ErbB family blockers afatinib and dacomitinib, a similar adverse event profile has been reported as for TKIs [55, 78, 90]. However, although the LUX-Lung 3 trial reported a median PFS of 13.6 months in patients with common mutations, this seems to have come at the cost of an increased rate of rash $(89 \%$, $7-22 \%$ grade $\geq 3)$ and diarrhea $(95 \%, 14.4 \%$ grade $\geq 3)$. This safety profile seems to be a class effect of irreversible ErbB family blockers [91]. Nevertheless, both the diarrhea and rash were manageable and, in LUX-Lung 3, the rate of afatinib discontinuation was low ( $8 \%$ vs. $12 \%$ in chemotherapytreated patients). Importantly, patients on afatinib reported better quality of life, measured by the European Organisation for Research and Treatment of Cancer (EORTC) quality-oflife questionnaire (QLQ) C-30, compared to those on chemotherapy [55].

\section{Conclusions, Clinical Recommendations, and Future Developments}

EGFR mutation-positive lung adenocarcinoma has emerged as a distinct subtype of lung cancer with respect to pathogenesis, prognosis, and treatment. In metastatic disease, erlotinib, gefitinib and, recently with the LUX-Lung 3 results, afatinib have been clinically validated as the most effective first-line agents for this tumor entity when compared to platinumbased chemotherapy. Activating EGFR gene mutations are the best predictors for EGFR TKI effectiveness; thus, EGFRmutational testing to guide treatment is justified in all patients with newly diagnosed metastatic pulmonary adenocarcinoma. Despite the fact that certain clinical determinants (e.g. neversmoking status, female sex, adenocarcinoma histology, Asian descent) are predictive of such mutations, general genetic testing is recommended to not withhold a superior therapy to patients with EGFR-mutant tumors not matching these clinical parameters. Contrariwise, EGFR TKIs may be even deleterious if given to patients with EGFR wild-type tumors [45]. Anyhow, despite its impressive superiority in terms of remission rates and PFS, no OS benefit of first-line EGFR TKI treatment over chemotherapy has been shown, neither in current phase III trials [48, 92] nor in meta-analyses [52]. This is most likely explained by confounding due to post-progression crossover of patients with EGFR-mutant tumors to second-line EGFR TKI treatment.

In general, small-molecule EGFR inhibitors are better tolerated than chemotherapy. Side effects like rash and diarrhea are manageable in the outpatient setting under close surveillance, in particular during the first weeks of treatment [86]. With the ErbB family blocker afatinib, patients experienced numerically more diarrhea and skin-related side effects compared to reports from studies using gefitinib or erlotinib. However, the quality of life of afatinib-treated patients was 
significantly better than that of chemotherapy-treated patients, which is in accordance with trials with erlotinib and gefitinib. Correspondingly, the discontinuation rate with afatinib was low [55]. Proactive and early treatment of adverse events for ErbB family blockers, including the use of skin moisturizers and sunscreen, sufficient fluid intake, and preemptive prescription of loperamide, as well as effective afatinib dose reduction schemes can efficiently help to maintain patients on treatment, thus increasing the quality of life and allowing the patients to obtain the maximum therapeutic benefit from this agent $[93,94]$. Head-to-head comparisons of afatinib with the established agents (LUX-Lung 7 and 8, both currently recruiting) will show whether afatinib - in parallel to the convincing clinical data with second-generation Bcr-Abl kinase inhibitors in the field of chronic myeloid leukemia (CML) [95] - has indeed better antitumor activity than firstgeneration TKIs. These trials will also help to define the best balance between activity and tolerability.

If not given upfront, all patients with EGFR mutationpositive lung adenocarcinoma must be offered an EGFR TKI latest during the further course of the disease, with ErbB family blockers as an improved treatment option in the future.
For patients with $E G F R$ wild-type tumors or with unknown $E G F R$ status, platinum-based combination chemotherapy remains the standard of care $[45,61]$. The long-term benefit of treatment with EGFR TKIs is limited by acquired resistance, and also primary resistance is encountered. Thus, future concepts like EGFR T790M mutant-selective kinase inhibitors [96] or combinatorial drug regimes - i.e. EGFR TKI plus c-Met inhibitors [97], EGFR TKI plus cetuximab [98] - are urgently needed and currently tested to prevent or overcome resistance against both EGFR TKIs and irreversible ErbB family blockers. In the future, this may help to transform advanced lung cancer from a terminal disease to a chronic illness to be managed over years $[99,100]$.

\section{Disclosure Statement}

J.K. received financial support from Boehringer Ingelheim for preparing this review article. He was fully responsible for all content and editorial decisions that reflect the authors' interpretation and conclusions. Boehringer Ingelheim was given the opportunity to check the data used in the manuscript for factual accuracy only.

\section{Literature}

1 Thun MJ,Hannan LM, Adams-Campbell LL, et al.: Lung cancer occurrence in never-smokers: an analysis of 13 cohorts and 22 cancer registry studies. PLoS Med 2008;5:e185.

2 Jemal A, Siegel R, Ward E, et al.: Cancer statistics, 2007. CA Cancer J Clin 2007;57:43-66.

3 Spiro SG, Silvestri GA: One hundred years of lung cancer. Am J Respir Crit Care Med 2005;172:523529 .

4 Demetri GD, von Mehren M, Blanke CD, et al.: Efficacy and safety of imatinib mesylate in advanced gastrointestinal stromal tumors. N Engl J Med 2002;347:472-480.

5 O'Brien SG, Guilhot F, Larson RA, et al.: Imatinib compared with interferon and low-dose cytarabine for newly diagnosed chronic-phase chronic myeloid leukemia. N Engl J Med 2003;348:994-1004.

6 Croce CM: Oncogenes and cancer. N Engl J Med 2008;358:502-511.

7 Weinstein IB: Cancer. Addiction to oncogenes the Achilles heal of cancer. Science 2002;297:63-64.

8 Cohen S: Isolation of a mouse submaxillary gland protein accelerating incisor eruption and eyelid opening in the new-born animal. J Biol Chem 1962; 237:1555-1562.

9 Ciardiello F, Tortora G: EGFR antagonists in cancer treatment. N Engl J Med 2008;358:1160-1174.

10 Ang KK, Berkey BA, Tu X, et al.: Impact of epidermal growth factor receptor expression on survival and pattern of relapse in patients with advanced head and neck carcinoma. Cancer Res 2002;62: 7350-7356.

11 Milas L, Fan Z, Andratschke NH, Ang KK: Epidermal growth factor receptor and tumor response to radiation: in vivo preclinical studies. Int $\mathrm{J}$ Radiat Oncol Biol Phys 2004;58:966-971.

12 Shepherd FA, Rodrigues Pereira J, Ciuleanu T, et al.: Erlotinib in previously treated non-small-cell lung cancer. N Engl J Med 2005;353:123-132.
13 Thatcher N, Chang A, Parikh P, et al.: Gefitinib plus best supportive care in previously treated patients with refractory advanced non-small-cell lung cancer: results from a randomised, placebo-controlled, multicentre study (Iressa Survival Evaluation in Lung Cancer). Lancet 2005;366:1527-1537.

14 Yang JC, Shih JY, Su WC, et al.: Afatinib for patients with lung adenocarcinoma and epidermal growth factor receptor mutations (LUX-Lung 2): a phase 2 trial. Lancet Oncol 2012;13:539-548.

15 Govindan R, Ding L, Griffith M, et al.: Genomic landscape of non-small cell lung cancer in smokers and never-smokers. Cell 2012;150:1121-1134.

16 Hirsch FR, Varella-Garcia M, Bunn PA Jr, et al.: Epidermal growth factor receptor in non-small-cell lung carcinomas: correlation between gene copy number and protein expression and impact on prognosis. J Clin Oncol 2003;21:3798-3807.

17 Paez JG, Janne PA, Lee JC, et al.: EGFR mutations in lung cancer: correlation with clinical response to gefitinib therapy. Science 2004;304:1497-1500.

18 Tang X, Shigematsu H, Bekele BN, et al.: EGFR tyrosine kinase domain mutations are detected in histologically normal respiratory epithelium in lung cancer patients. Cancer Res 2005;65:75687572.

19 Yatabe Y: EGFR mutations and the terminal respiratory unit. Cancer Metastasis Rev 2010;29:23-36.

20 Centeno I, Blay P, Santamaria I, et al.: Germ-line mutations in epidermal growth factor receptor (EGFR) are rare but may contribute to oncogenesis: a novel germ-line mutation in EGFR detected in a patient with lung adenocarcinoma. BMC Cancer 2011;11:172.

21 Lynch TJ, Bell DW, Sordella R, et al.: Activating mutations in the epidermal growth factor receptor underlying responsiveness of non-small-cell lung cancer to gefitinib. N Engl J Med 2004;350:21292139.
22 Tanaka T, Matsuoka M, Sutani A, et al.: Frequency of and variables associated with the EGFR mutation and its subtypes. Int J Cancer 2010;126:651655.

23 Shigematsu H, Lin L, Takahashi T, et al.: Clinical and biological features associated with epidermal growth factor receptor gene mutations in lung cancers. J Natl Cancer Inst 2005;97:339-346.

24 Shim HS, Lee da H, Park EJ, Kim SH: Histopathologic characteristics of lung adenocarcinomas with epidermal growth factor receptor mutations in the International Association for the Study of Lung Cancer/American Thoracic Society/European Respiratory Society lung adenocarcinoma classification. Arch Pathol Lab Med 2011;135:13291334.

25 Thu KL, Vucic EA, Chari R, et al.: Lung adenocarcinoma of never smokers and smokers harbor differential regions of genetic alteration and exhibit different levels of genomic instability. PLoS One 2012;7:e33003.

$26 \mathrm{Wu}$ M, Zhao J, Song SW, et al.: EGFR mutations are associated with prognosis but not with the response to front-line chemotherapy in the Chinese patients with advanced non-small cell lung cancer. Lung Cancer 2010;67:343-347.

27 Tsao MS, Sakurada A, Ding K, et al.: Prognostic and predictive value of epidermal growth factor receptor tyrosine kinase domain mutation status and gene copy number for adjuvant chemotherapy in non-small cell lung cancer. J Thorac Oncol 2011; 6:139-147.

28 Eberhard DA, Johnson BE, Amler LC, et al.: Mutations in the epidermal growth factor receptor and in KRAS are predictive and prognostic indicators in patients with non-small-cell lung cancer treated with chemotherapy alone and in combination with erlotinib. J Clin Oncol 2005;23:59005909. 
29 Sakurada A, Shepherd FA, Tsao MS: Epidermal growth factor receptor tyrosine kinase inhibitors in lung cancer: impact of primary or secondary mutations. Clin Lung Cancer 2006;7(suppl 4):S138-S144.

30 Carey KD, Garton AJ, Romero MS, et al.: Kinetic analysis of epidermal growth factor receptor somatic mutant proteins shows increased sensitivity to the epidermal growth factor receptor tyrosine kinase inhibitor, erlotinib. Cancer Res 2006;66: 8163-8171.

31 Massarelli E, Varella-Garcia M, Tang X, et al. KRAS mutation is an important predictor of resistance to therapy with epidermal growth factor receptor tyrosine kinase inhibitors in non-smallcell lung cancer. Clin Cancer Res 2007;13:28902896.

32 Burns DM, Anderson CM, Gray N: Do changes in cigarette design influence the rise in adenocarcinoma of the lung? Cancer Causes Control 2011; 22:13-22.

33 Giaccone G, Gallegos Ruiz M, Le Chevalier T, et al.: Erlotinib for frontline treatment of advanced non-small cell lung cancer: a phase II study. Clin Cancer Res 2006;12:6049-6055.

34 Reck M, Buchholz E, Romer KS, et al.: Gefitinib monotherapy in chemotherapy-naive patients with inoperable stage III/IV non-small-cell lung cancer. Clin Lung Cancer 2006;7:406-411.

35 Akerley W, Boucher KM, Bentz JS, Arbogast K, Walters T: A phase II study of erlotinib as initial treatment for patients with stage IIIB-IV nonsmall cell lung cancer. J Thorac Oncol 2009;4:214219.

36 Jackman DM, Yeap BY, Lindeman NI, et al.: Phase II clinical trial of chemotherapy-naive patients $>$ or $=70$ years of age treated with erlotinib for advanced non-small-cell lung cancer. J Clin Oncol 2007;25:760-766

37 Hesketh PJ, Chansky K, Wozniak AJ, et al.: Southwest Oncology Group phase II trial (S0341) of erlotinib (OSI-774) in patients with advanced nonsmall cell lung cancer and a performance status of 2. J Thorac Oncol 2008;3:1026-1031.

38 Crino L, Cappuzzo F, Zatloukal P, et al.: Gefitinib versus vinorelbine in chemotherapy-naive elderly patients with advanced non-small-cell lung cancer (INVITE): a randomized, phase II study. J Clin Oncol 2008;26:4253-4260.

39 Lilenbaum R, Axelrod R, Thomas S, et al.: Randomized phase II trial of erlotinib or standard chemotherapy in patients with advanced nonsmall-cell lung cancer and a performance status of 2. J Clin Oncol 2008;26:863-869.

40 Lee SM, Khan I, Upadhyay S, et al.: First-line erlotinib in patients with advanced non-small-cell lung cancer unsuitable for chemotherapy (TOPICAL): a double-blind, placebo-controlled, phase 3 trial. Lancet Oncol 2012;13:1161-1170.

41 Morere JF, Brechot JM, Westeel V, et al.: Randomized phase II trial of gefitinib or gemcitabine or docetaxel chemotherapy in patients with advanced non-small-cell lung cancer and a performance status of 2 or 3 (IFCT-0301 study). Lung Cancer 2010;70:301-307.

42 Goss G, Ferry D, Wierzbicki R, et al.: Randomized phase II study of gefitinib compared with placebo in chemotherapy-naive patients with advanced non-small-cell lung cancer and poor performance status. J Clin Oncol 2009;27:2253-2260.

43 Yang CH, Yu CJ, Shih JY, et al.: Specific EGFR mutations predict treatment outcome of stage IIIB/IV patients with chemotherapy-naive nonsmall-cell lung cancer receiving first-line gefitinib monotherapy. J Clin Oncol 2008;26:2745-2753.
44 Niho S, Kubota K, Goto K, et al.: First-line single agent treatment with gefitinib in patients with advanced non-small-cell lung cancer: a phase II study. J Clin Oncol 2006;24:64-69.

45 Mok TS, Wu YL, Thongprasert S, et al.: Gefitinib or carboplatin-paclitaxel in pulmonary adenocarcinoma. N Engl J Med 2009;361:947-957.

46 Ebi N, Semba H, Tokunaga SJ, et al.: A phase II trial of gefitinib monotherapy in chemotherapynaive patients of 75 years or older with advanced non-small cell lung cancer. J Thorac Oncol 2008; 3:1166-1171.

47 Zhou C, Wu YL, Chen G, et al.: Erlotinib versus chemotherapy as first-line treatment for patients with advanced EGFR mutation-positive nonsmall-cell lung cancer (OPTIMAL, CTONG-0802): a multicentre, open-label, randomised, phase 3 study. Lancet Oncol 2011;12:735-742.

48 Maemondo M, Inoue A, Kobayashi $\mathrm{K}$, et al.: Gefitinib or chemotherapy for non-small-cell lung cancer with mutated EGFR. N Engl J Med 2010; 362:2380-2388.

49 Rosell R, Carcereny E, Gervais R, et al.: Erlotinib versus standard chemotherapy as first-line treatment for European patients with advanced EGFR mutation-positive non-small-cell lung cancer (EURTAC): a multicentre, open-label, randomised phase 3 trial. Lancet Oncol 2012;13:239-246.

50 Mitsudomi T, Morita S, Yatabe Y, et al.: Gefitinib versus cisplatin plus docetaxel in patients with non-small-cell lung cancer harbouring mutations of the epidermal growth factor receptor (WJTOG3405): an open label, randomised phase 3 trial. Lancet Oncol 2010;11:121-128.

51 Dahabreh IJ, Linardou H, Siannis F, et al.: Somatic EGFR mutation and gene copy gain as predictive biomarkers for response to tyrosine kinase inhibitors in non-small cell lung cancer. Clin Cancer Res 2010;16:291-303.

52 Petrelli F, Borgonovo K, Cabiddu M, Barni S: Efficacy of EGFR tyrosine kinase inhibitors in patients with EGFR-mutated non-small-cell lung cancer: a meta-analysis of 13 randomized trials. Clin Lung Cancer 2012;13:107-114.

53 Jackman DM, Miller VA, Cioffredi LA, et al.: Impact of epidermal growth factor receptor and KRAS mutations on clinical outcomes in prezviously untreated non-small cell lung cancer patients: results of an online tumor registry of clinical trials. Clin Cancer Res 2009;15:5267-5273.

54 Fukuoka M, Wu YL, Thongprasert S, et al.: Biomarker analyses and final overall survival results from a phase III, randomized, open-label, first-line study of gefitinib versus carboplatin/paclitaxel in clinically selected patients with advanced nonsmall-cell lung cancer in Asia (IPASS). J Clin Oncol 2011;29:2866-2874.

55a Sequist LV, Yang JC, Yamamoto N, et al.: Phase III study of afatinib or cisplatin plus pemetrexed in patiens with metastatic lung adenocarinoma with EGFR mutations. J Clin Oncol 2013 DOI: 10,1200/ JCO.2012.44,2806.

55b Yang JC, Hirsh V, Schuler M, et al.: Symptom control and quality of life in LUX-Lung 3: a phase III strudy of afatinib or cisplatin/pemetrexed in patients with advanced lung adenocarcinoma with EGFR mutations. J Clin Oncol 2013 DOI: 10,1200/ JCO.2012.46,1764.

56 Wu JY, Yu CJ, Yang CH, et al.: First- or second-line therapy with gefitinib produces equal survival in non-small cell lung cancer. Am J Respir Crit Care Med 2008;178:847-853.

57 Zhang L, Ma S, Song X, et al.: Gefitinib versus placebo as maintenance therapy in patients with locally advanced or metastatic non-small-cell lung cancer (INFORM; C-TONG 0804): a multicentre, double-blind randomised phase 3 trial. Lancet Oncol 2012;13:466-475.

58 Cappuzzo F, Ciuleanu T, Stelmakh L, et al. Erlotinib as maintenance treatment in advanced non-small-cell lung cancer: a multicentre, randomised, placebo-controlled phase 3 study. Lancet Oncol 2010;11:521-529.

59 Oizumi S, Kobayashi K, Inoue A, et al.: Quality of life with gefitinib in patients with EGFR-mutated non-small cell lung cancer: quality of life analysis of North East Japan Study Group 002 Trial. Oncologist 2012;17:863-870.

60 Asami K, Koizumi T, Hirai K, et al.: Gefitinib as first-line treatment in elderly epidermal growth factor receptor-mutated patients with advanced lung adenocarcinoma: results of a Nagano Lung Cancer Research Group study. Clin Lung Cancer 2011;12:387-392.

61 Gridelli C, Butts C, Ciardiello F, et al.: An international, multicenter, randomized phase III study of first-line erlotinib followed by second-line cisplatin/gemcitabine versus first-line cisplatin/gemcitabine followed by second-line erlotinib in advanced non-small-cell lung cancer: treatment rationale and protocol dynamics of the TORCH trial. Clin Lung Cancer 2008;9:235-238.

62 Thomas M, Reuss A, Fischer JR, et al.: Innovations: Randomized phase II trial of erlotinib (E)/bevacizumab (B) compared with cisplatin (P)/gemcitabine $(\mathrm{G})$ plus $\mathrm{B}$ in first-line treatment of advanced nonsquamous (NS) non-small cell lung cancer (NSCLC). J Clin Oncol 2011;29(suppl);abstr 7504.

63 Giaccone G, Herbst RS, Manegold C, et al.: Gefitinib in combination with gemcitabine and cisplatin in advanced non-small-cell lung cancer: a phase III trial - INTACT 1. J Clin Oncol 2004; 22:777-784.

64 Herbst RS, Giaccone G, Schiller JH, et al. Gefitinib in combination with paclitaxel and carboplatin in advanced non-small-cell lung cancer: a phase III trial - INTACT 2. J Clin Oncol 2004;22:785-794.

65 Janne PA, Wang X, Socinski MA, et al.: Randomized phase II trial of erlotinib alone or with carboplatin and paclitaxel in patients who were never or light former smokers with advanced lung adenocarcinoma: CALGB 30406 trial. J Clin Oncol 2012:30:2063-2069.

66 Oxnard GR, Arcila ME, Chmielecki J, et al.: New strategies in overcoming acquired resistance to epidermal growth factor receptor tyrosine kinase inhibitors in lung cancer. Clin Cancer Res 2011; 17:5530-5537.

67 Yun $\mathrm{CH}$, Mengwasser KE, Toms AV, et al.: The T790M mutation in EGFR kinase causes drug resistance by increasing the affinity for ATP. Proc Natl Acad Sci USA 2008;105:2070-2075.

$68 \mathrm{Su}$ KY, Chen HY, Li KC, et al.: Pretreatment epidermal growth factor receptor (EGFR) T790M mutation predicts shorter EGFR tyrosine kinase inhibitor response duration in patients with nonsmall-cell lung cancer. J Clin Oncol 2012;30:433440.

69 Yu HA, Arcila ME, Rekhtman N, et al.: Analysis of tumor specimens at the time of acquired resistance to EGFR-TKI therapy in 155 patients with EGFRmutant lung cancers. Clin Cancer Res 2013;19: 2240-2247.

70 Mink SR, Vashistha S, Zhang W, et al.: Cancerassociated fibroblasts derived from EGFR-TKIresistant tumors reverse EGFR pathway inhibition by EGFR-TKIs. Mol Cancer Res 2010;8:809-820. 
71 Takezawa K, Pirazzoli V, Arcila ME, et al.: HER2 amplification: a potential mechanism of acquired resistance to EGFR inhibition in EGFR-mutant lung cancers that lack the second-site EGFRT790M mutation. Cancer Discov 2012;2:922-933.

72 Shigematsu H, Takahashi T, Nomura M, et al. Somatic mutations of the HER2 kinase domain in lung adenocarcinomas. Cancer Res 2005;65:16421646.

73 Nakamura H, Kawasaki N, Taguchi M, Kabasawa K: Association of HER-2 overexpression with prognosis in nonsmall cell lung carcinoma: a metaanalysis. Cancer 2005;103:1865-1873.

74 Sergina NV, Rausch M, Wang D, et al.: Escape from HER-family tyrosine kinase inhibitor therapy by the kinase-inactive HER3. Nature 2007; 445:437-441.

75 Bean J, Riely GJ, Balak M, et al.: Acquired resistance to epidermal growth factor receptor kinase inhibitors associated with a novel T854A mutation in a patient with EGFR-mutant lung adenocarcinoma. Clin Cancer Res 2008;14:7519-7525.

76 Li D, Ambrogio L, Shimamura T, et al.: BIBW2992, an irreversible EGFR/HER2 inhibitor highly effective in preclinical lung cancer models. Oncogene 2008;27:4702-4711.

77 Miller VA, Hirsh V, Cadranel J, et al.: Afatinib versus placebo for patients with advanced, metastatic non-small-cell lung cancer after failure of erlotinib, gefitinib, or both, and one or two lines of chemotherapy (LUX-Lung 1): a phase $2 b / 3$ randomised trial. Lancet Oncol 2012;13:528-538.

78 Murakami H, Tamura T, Takahashi T, et al.: Phase I study of continuous afatinib (BIBW 2992) in patients with advanced non-small cell lung cancer after prior chemotherapy/erlotinib/gefitinib (LUXLung 4). Cancer Chemother Pharmacol 2012;69: 891-899.

79 Scagliotti GV, Parikh P, von Pawel J, et al.: Phase III study comparing cisplatin plus gemcitabine with cisplatin plus pemetrexed in chemotherapynaive patients with advanced-stage non-small-cell lung cancer. J Clin Oncol 2008;26:3543-3551.

80 Einhorn LH: First-line chemotherapy for nonsmall-cell lung cancer: is there a superior regimen based on histology? J Clin Oncol 2008;26:34853486.

81 O'Brien ME, Borthwick A, Rigg A, et al.: Mortality within 30 days of chemotherapy: a clinical governance benchmarking issue for oncology patients. Br J Cancer 2006;95:1632-1636

82 Ren S, Li Y, Li W, et al.: Fatal asymmetric interstitial lung disease after erlotinib for lung cancer. Respiration 2012;84:431-435.

83 Schacher-Kaufmann S, Pless M: Acute fatal liver toxicity under erlotinib. Case Rep Oncol 2010;3: 182-188.

84 Petrelli F, Borgonovo K, Cabiddu M, Lonati V, Barni S: Relationship between skin rash and outcome in non-small-cell lung cancer patients treated with anti-EGFR tyrosine kinase inhibitors: a literature-based meta-analysis of 24 trials. Lung Cancer 2012;78:8-15.
85 Perez-Soler R, Delord JP, Halpern A, et al.: HER1/ EGFR inhibitor-associated rash: future directions for management and investigation outcomes from the HER1/EGFR inhibitor rash management forum. Oncologist 2005;10:345-356.

86 Hirsh V: Managing treatment-related adverse events associated with EGFR tyrosine kinase inhibitors in advanced non-small-cell lung cancer. Curr Oncol 2011;18:126-138.

87 Saltz LB: Understanding and managing chemotherapy-induced diarrhea. J Support Oncol 2003;1: 35-46; discussion 38-41, 45-36.

88 Maroun JA, Anthony LB, Blais N, et al.: Prevention and management of chemotherapy-induced diarrhea in patients with colorectal cancer: a consensus statement by the Canadian Working Group on Chemotherapy-Induced Diarrhea. Curr Oncol 2007;14:13-20.

89 Nakagawa M, Nishimura T, Teramukai S, et al.: Interstitial lung disease in gefitinib-treated Japanese patients with non-small cell lung cancer - a retrospective analysis: JMTO LC03-02. BMC Res Notes 2009;2:157.

90 Yoneda KY, Hardin KA, Gandara DR, Shelton DK: Interstitial lung disease associated with epidermal growth factor receptor tyrosine kinase inhibitor therapy in non-small-cell lung carcinoma. Clin Lung Cancer 2006;8(suppl 1):S31-S35.

91 Boyer MJ, Blackhall FH, Park K, et al.: Efficacy and safety of PF299804 versus erlotinib (E): a global, randomized phase II trial in patients (pts) with advanced non-small cell lung cancer (NSCLC) after failure of chemotherapy (CT). J Clin Oncol 2010;28(suppl 18s):abstr LBA7523.

92 Zhou C, Wu Y, Liu X, et al.: Overall survival (OS) results from OPTIMAL (CTONG0802), a phase III trial of erlotinib (E) versus carboplatin plus gemcitabine (GC) as first-line treatment for Chinese patients with EGFR mutation-positive advanced non-small cell lung cancer (NSCLC). J Clin Oncol 2012;30(suppl):abstr 7520.

93 Yang JC, Reguart N, Barinoff J, et al.: Diarrhea associated with afatinib: an oral ErbB family blocker. Expert Rev Anticancer Ther 2013;13:729736.

94 Lacouture ME, Schadendorf D, Chu CY, et al.: Dermatologic adverse events associated with afatinib: an oral ErbB family blocker. Expert Rev Anticancer Ther 2013;13:721-728.

95 Kantarjian H, Shah NP, Hochhaus A, et al: Dasatinib versus imatinib in newly diagnosed chronic-phase chronic myeloid leukemia. N Engl J Med 2010;362:2260-2270.

96 Zhou W, Ercan D, Chen L, et al.: Novel mutantselective EGFR kinase inhibitors against EGFR T790M. Nature 2009;462:1070-1074.

97 Spigel DR, Ervin TJ, Ramlau R, et al.: Final efficacy results from OAM4558g, a randomized phase II study evaluating MetMAb or placebo in combination with erlotinib in advanced NSCLC. J Clin Oncol 2011;29(suppl):abstr 7505.
98 Janjigian YY, Groen HJM, Horn L, et al.: Activity and tolerability of afatinib (BIBW 2992) and cetuximab in NSCLC patients with acquired resistance to erlotinib or gefitinib. J Clin Oncol 2011;29(suppl):abstr 7525.

99 Nguyen KS, Kobayashi S, Costa DB: Acquired resistance to epidermal growth factor receptor tyrosine kinase inhibitors in non-small-cell lung cancers dependent on the epidermal growth factor receptor pathway. Clin Lung Cancer 2009;10: 281-289.

100 Cortot AB, Repellin CE, Shimamura T, et al. Resistance to irreversible EGFR tyrosine kinase inhibitors through a multistep mechanism involving the IGF1R pathway. Cancer Res 2013;73:834843.

101 West HL, Franklin WA, McCoy J, et al.: Gefitinib therapy in advanced bronchioloalveolar carcinoma: Southwest Oncology Group Study S0126. J Clin Oncol 2006;24:1807-1813.

102 Cadranel J, Quoix E, Baudrin L, et al.: IFCT-0401 trial: a phase II study of gefitinib administered as first-line treatment in advanced adenocarcinoma with bronchioloalveolar carcinoma subtype. J Thorac Oncol 2009;4:1126-1135.

103 Lee DH, Han JY, Lee HG, et al.: Gefitinib as a first-line therapy of advanced or metastatic adenocarcinoma of the lung in never-smokers. Clin Cancer Res 2005;11:3032-3037.

104 Jackman DM, Cioffredi L, Lindeman NI: Phase II trial of erlotinib in chemotherapy-naive women with advanced pulmonary adenocarcinoma. J Clin Oncol 2009;27(suppl 15S):abstr 8065.

105 Han JY, Park K, Kim SW, et al.: First-SIGNAL: first-line single-agent Iressa versus gemcitabine and cisplatin trial in never-smokers with adenocarcinoma of the lung. J Clin Oncol 2012;30:11221128.

106 Asahina H, Yamazaki K, Kinoshita I, et al.: A phase II trial of gefitinib as first-line therapy for advanced non-small cell lung cancer with epidermal growth factor receptor mutations. Br J Cancer 2006;95:998-1004.

107 Inoue A, Suzuki T, Fukuhara T, et al.: Prospective phase II study of gefitinib for chemotherapynaive patients with advanced non-small-cell lung cancer with epidermal growth factor receptor gene mutations. J Clin Oncol 2006;24:3340-3346.

108 Sequist LV, Martins RG, Spigel D, et al.: First-line gefitinib in patients with advanced non-small-cell lung cancer harboring somatic EGFR mutations. J Clin Oncol 2008;26:2442-2449.

109 Rosell R, Moran T, Queralt C, et al.: Screening for epidermal growth factor receptor mutations in lung cancer. N Engl J Med 2009;361:958-967.

110 Inoue A, Kobayashi K, Usui K, et al.: First-line gefitinib for patients with advanced non-smallcell lung cancer harboring epidermal growth factor receptor mutations without indication for chemotherapy. J Clin Oncol 2009;27:13941400 . 